\title{
Reproductive biology of Protium spruceanum (Burseraceae), a dominant dioecious tree in vegetation corridors in Southeastern Brazil
}

\author{
FÁBIO DE ALMEIDA VIEIRA ${ }^{1,4}$, VIVETTE APPOLINÁRIO², CRISTIANE GOUVÊA FAJARDO \\ and DULCINÉIA DE CARVALHO
}

(recebido: 19 de março de 2010; aceito: 22 de outubro de 2010)

\begin{abstract}
Reproductive biology of Protium spruceanum (Burseraceae), a dominant dioecious tree in vegetation corridors in Southeastern Brazil). We investigated the reproductive biology of Protium spruceanum (Benth.) Engler in vegetation corridors of secondary Atlantic forest in Lavras, southern Minas Gerais State, Brazil. The reproductive phenology was investigated fortnightly over a one year period. Floral biology studies involved pollen viability analysis, nectar production, stigmatic receptivity, pollen tube growth, visiting insect species and visit rates. The small, pale yellowish flowers (0.3-0.4 cm diameter) are functionally unisexual and organized in dense inflorescences (ca. 45 flowers). P. spruceanum presented annual flowering between September and November. Staminate flowers supplied a high percentage of viable pollen $(90.6 \%)$ and relatively abundant nectar $(\bar{x}=4.5 \mu \mathrm{L})$. Pistillate flowers produced only nectar to flower visitors $(\bar{x}=4.0 \mu \mathrm{L})$. The effective pollinators were Apis mellifera and Trigona sp. (Hymenoptera, Apidae). Pollen tubes of cross-pollinated flowers were observed entering the ovaries $48 \mathrm{~h}$ after pollination. The fruiting season is from October to March, with a peak in November, coinciding with the rainfall peak. Ecological implications of these findings, and alternative arguments to explain the high genetic diversity at regional landscape are discussed.
\end{abstract}

Key words - dioecy, floral visitors, flowering, fruiting, secondary forest

RESUMO - (Biologia reprodutiva de Protium spruceanum (Burseraceae), uma espécie arbórea dioica e dominante em corredores de vegetação no sudeste do Brasil). A fenologia e a biologia reprodutiva de Protium spruceanum (Benth.) Engl. foram avaliadas mediante observações quinzenais pelo período de um ano, em corredores de vegetação secundária em Lavras, sul de Minas Gerais. As análises da biologia floral compreenderam a viabilidade polínica, produção de néctar, receptividade estigmática, crescimento do tubo polínico, visitantes florais e taxas de visitas. As flores são pequenas (0,3-0,4 cm de diâmetro), de cor amarela clara, funcionalmente unissexuais e dispostas em densas inflorescências (média de 45 flores). P. spruceanum apresentou floração anual e massiva entre setembro e novembro. As flores estaminadas produzem alta porcentagem de pólen viável $(90,6 \%)$ e quantidade de néctar $(\bar{x}=4,5 \mu \mathrm{L})$. Flores pistiladas oferecem apenas néctar para os visitantes $(\bar{x}=4,0 \mu \mathrm{L})$. Os polinizadores efetivos são Apis mellifera e Trigona sp. (Hymenoptera, Apidae). Os tubos polínicos de flores de polinização cruzada foram observados na base do estilete e no ovário após $48 \mathrm{~h}$ da polinização. A frutificação ocorre entre outubro e março, com pico em novembro, coincidindo com o período de maior precipitação. São discutidas as implicações ecológicas dos resultados e os argumentos para explicar a alta diversidade genética da espécie na paisagem local.

Palavras-chave - dioicia, floração, floresta secundária, frutificação, visitantes florais

\section{Introduction}

Many members of the Burseraceae family, which are well-known sources of gums and resins (Sunnichan et al. 2005), are dioecious and produce small flowers. Information on their reproductive biology however is available for only a few species of this family (Gupta et

1. Universidade Federal do Rio Grande do Norte, Departamento de Agropecuária, 59072-970 Natal, RN, Brasil.

2. Universidade Federal de Lavras, Departamento de Ciências Florestais, Caixa Postal 3037, 37200-000 Lavras, MG, Brasil.

3. Universidade Federal do Rio Grande do Norte, Programa de Pósgraduação em Ecologia, 59072-970 Natal, RN, Brasil.

4._Corresponding author: vieirafa@ufrnet.br al. 1996, Farwig et al.2004, Sunnichan et al. 2005, Voigt et al.2005). Protium Burm. f. is a genus of approximately 146 species, occurring mainly in neotropical regions. The primary centre of diversity is in the Amazon rainforest, where 73 species occur, of which 42 are endemic to the region (Daly 1992). Protium spruceanum (Benth.) Engler, locally known as breu, is a large canopy tree (up to $20 \mathrm{~m}$ tall), found in the Amazon and Atlantic rainforests and on the cerrado riverbank woodland (Oliveira Filho \& Ratter 1995).

The Brazilian Atlantic forest, in the southern part of the Minas Gerais State, has been seriously exploited since European occupation two centuries ago resulting in the fragmentation and isolation of the forests. At the 
same time, ditches to divide rural properties (ca. 4-6 m wide) were constructed by slaves, resulting in vegetation corridors, that is, second-growth colonization by native tree species that connect small fragments of forest (Vieira \& Carvalho 2008). In our previous research, a study of $P$. spruceanum throughout the fragments of Brazilian Atlantic forest and corridors of secondary forest revealed that the species exhibited high levels of genetic diversity (Vieira \& Carvalho 2008). However, no data about reproductive biology of this species were available. Correlations between genetic variation and reproductive data have been shown to be linked (Crawford \& Elisens 2006, Mateu-Andrés \& Paco 2006). For this, we investigated the reproductive biology and phenology of $P$. spruceanum, in the Atlantic forest in Lavras, southern Minas Gerais, Brazil.

\section{Materials and methods}

Study site - Because trees are concentrated in lower-height reproductive classes rather than in fragments, this study was conducted in vegetation corridors, located in the city of Lavras, in southern Minas Gerais State, Brazil (21¹7'33” S and 44 $59^{\prime} 15^{\prime \prime} \mathrm{W}, 21^{\circ} 18^{\prime} 11^{\prime \prime} \mathrm{S}$ and 44 59'18' W). The region is characterized by a Köppen type Cwa climate, with a rainy summer and a dry winter season, with mean annual rainfall of approximately $1,500 \mathrm{~mm}$ and mean annual temperature of approximately $20^{\circ} \mathrm{C}$. The current landscape comprises a number of forest fragments and a matrix of planted pastures and vegetation corridors of secondary forest (Vieira \& Carvalho 2008). Fragments and vegetation corridors are similar in terms of floristic composition, but corridors have larger basal areas and trees are concentrated in the upper diameter classes and lower height classes. In the corridors studied, Protium spruceanum, along with companion tree species such as Tapirira guianensis Aublet (Anacardiaceae), Copaifera langsdorffii Desf. (Fabaceae) and Ocotea pulchella Mart. (Lauraceae) are the most abundant species $\left(>120\right.$ trees $\mathrm{ha}^{-1}$ ) of the mass-flowering/insect-pollinated and bird-dispersed tree species. The absolute density of $P$. spruceanum in these corridors was estimated as 135 trees ha-1 (G.C. Castro, unpublished data).

Phenological observations - Phenological observations for all reproductive trees were made fortnightly from November 2005 to December 2006, recording initial and final phenological periods. Absence or presence of buds, flowers and fruits were recorded in four vegetation corridors ( $c a$. 2,650 m length). Flowering (anthesis) and fruiting (green and ripe fruit) were recorded as the presence of one or more open flowers or one or more fruit, respectively. Rainfall and temperature data were available during phenological observations from the Estação Meteorológica da Universidade Federal de Lavras (approximately $8 \mathrm{~km}$ north of study site). Number of flowers at anthesis per inflorescence was estimated by counting the number of flowers in seven trees (2-4 inflorescences per tree).

Floral biology - Nectar volume and sugar concentration were measured on 61 bagged flowers from six trees, using graduated micro-capillaries and a hand refractometer. The volume and concentration of the accumulated nectar were estimated at approximately $08 \mathrm{~h} 00$, when anthesis had started. Pollen viability was estimated in 13 male flowers, using the acetocarmine staining technique, under a microscope (Kearns \& Inouye 1993). Stigmatic receptivity was determined through the peroxidase activity technique (Kearns \& Inouye 1993), between $08 \mathrm{~h} 00$ and $15 \mathrm{~h} 00$, in both sexual morphs $(n=69$, from six trees).

Pollen tube growth - Pollinated flowers resulting from cross-pollinations were collected, the pistils removed, and fixed with FAA for 24 hours. Following this, they were transferred to ethanol $(70 \%)$ and then stored at $8{ }^{\circ} \mathrm{C}$. Pollen tube growth was investigated in pistils fixed 24 and $48 \mathrm{~h}$ after hand pollination. The pistils were softened for $30 \mathrm{~min}$ in $\mathrm{NaOH} 6 \mathrm{M}$ in a water bath $\left(60^{\circ} \mathrm{C}\right)$ and then rinsed in water. The pistils were stained with $0.1 \%$ aniline blue for $4 \mathrm{~h}$, squashed under a cover-slip, and observed under a fluorescence microscope (Olympus BX 60, USA).

Floral visitors - Floral visitor activity was recorded during two days of field observations, usually from $07 \mathrm{~h} 00$ to $16 \mathrm{~h} 00$, during massive flowering. Three observers working separately enabled approximately 54 hours of observations to be recorded. The resource gathering and movements regarding contact with stigma were recorded for all visitors. At least two individuals of each visitor morphospecies were captured for identification. The frequency curves of floral visitor were compared by Kolmogorov-Smirnov’s nonparametric test.

\section{Results}

Protium spruceanum presented massive annual flowering, between September and November. Overall reproductive activity was greatest in the rainy season and lower or absent in the dry season. Floral buds started to develop in July, in the transition period from dry to wet season. Flowering commenced with the beginning of the rains. The trees had dense inflorescences (median $=45$ flowers, range $=15-87, n=22$ ). The species is cryptically dioecious, with apparently perfect flowers possessing either rudimentary gynoecium lacking ovules (male plant) or vestigial anthers with no pollen (female plant). Anthesis started in the early morning and flower opening occurred during the day for flowers of both sexes. Staminate flowers supplied a high percentage of viable pollen $(90.6 \% \pm 1.2$ s.e, $n=13$ flowers $)$ coinciding with the receptive phase of the stigma of the pistillate 
flowers that started immediately after flowering and extended throughout the day. Staminate and pistillate flowers produced relatively abundant nectar (4.5 and $4.0 \mu \mathrm{L}$, respectively), with an average of $28.3 \%$ and $32 \%$ concentration in sucrose equivalents, respectively.

The flowers of $P$. spruceanum were visited by a low total number of insect species, including bees, wasps, flies and small ants. The bees Apis mellifera and Trigona sp. (Hymenoptera, Apidae) were the most frequent visiting species (figure 1), probably due to the high number of flowers/inflorescence of $P$. spruceanum in the corridors of secondary forest. Trigona sp. individuals remained for several minutes foraging on a single flower. They remained most of the time in a single plant, compared to A. mellifera, that restricted their visits to less than a minute per flower and foraged a few flowers per plant (personal observation). Agonistic interespecific encounters were not common. The flowers of $P$. spruceanum were visited mainly between $09 \mathrm{~h} 00-12 \mathrm{~h} 00$ when most of the floral visitors contacted anthers and stigma. The difference in the frequency of visits between Apis mellifera and Trigona sp. was not significant $(P=0.090, \alpha=0.05$ by Kolmogorov-Smirnov's test) (figure 1).

Cross-pollens on pistils germinate and tubes grow down the pistils for up to $24 \mathrm{~h}$. Pollen tubes of cross-pollinated flowers were observed at the base of the pistils until $48 \mathrm{~h}$ after pollination. The mediumsized, bird-dispersed seeds $(<500 \mathrm{mg}$ fresh weight) are produced in reddish berries in the canopy of adult trees and are dispersed from October to March, with a peak in November, coincidently when the rainfall peaks. The fruits have an outer covering that splits in half when mature, exposing between one and three grey seeds enveloped by a fleshy white aril. The fruits are dispersed by birds.

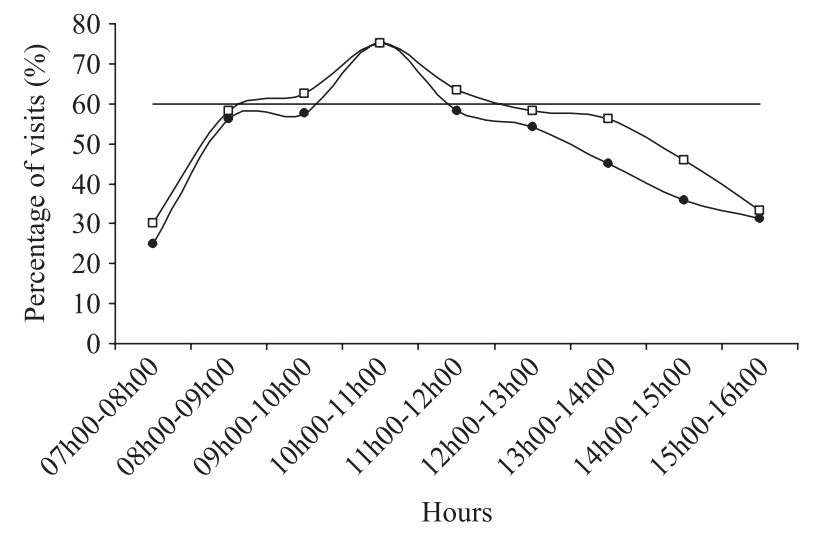

Figure 1. Frequency of visits of Apis mellifera (-口-) and Trigona sp. (--) on flowers of Protium spruceanum during the monitored hours. The line in the percentage 60 detaches the periods of high floral visits $(>60 \%)$.

\section{Discussion}

The phenological pattern in our study showed a trend towards a concentration of flowering and fruiting of $P$. spruceanum in the early wet seasons at the warmest period of the year. This is in accordance with the general findings in the tropics, particularly where there is climatic seasonality (Schaik et al. 1993). Likewise, in Atlantic forest the flowering is, in general, highly seasonal and concentrated at the beginning of the wetter season (Morellato et al. 2000). This might be a consequence of marked irregularity in rainfall distribution and amount, that could be expected to lead to irregularity in flowering for certain species. The development of ripe fruits at the beginning of the warm and wet season is likely to be adaptive, so that germination and establishment can take place while water is plentiful (Schaik et al. 1993). Indeed, visual observations in the field indicate that germination of seeds and $P$. spruceanum seedling emergence occur in the rainy season.

Spatial patterns of genetic variation within populations depend primarily on the patterns and distance of pollen and outcrossing rates and these results have often been interpreted as the consequence of intense gene flow (Doligez \& Joly 1997, Streiff et al. 1998). Two of the most observed visitors of dense inflorescences of P. spruceanum are Apis mellifera and Trigona sp., and the opportunistic behavior of such family (Apidae) has been reported in many habitats and associated with plant density and clusters (Ramalho 1990). Thought exotic honeybees can be important competitors of native pollinators (Carmo et al. 2004), sometimes they have neutral or even beneficial effects on the pollination of native plants (Gross 2001, Dick et al. 2003, Suzuki 2003), because of their high density, social organization and propensity for agricultural landscapes (Dick et al. 2003). High temperatures around midday could result in high insect activity, as observed in this study, and this could lead to high visiting rates (Arroyo et al. 1985).

Apis mellifera and Trigona sp. bees were considered efficient pollinators due to their frequency of visits at the flowers and also because they could easily contact anthers and stigmas. This is consistent with other studies with bees being the most important pollinators for other tropical tree species of the family Burseraceae (Bawa 1990, Farwig et al. 2004, Voigt et al. 2005). In a review about outcrossing and pollen-mediated gene flow in neotropical trees, Ward et al. (2005) found no mating system studies (e.g. paternity analysis) for species of Burseraceae. However, Dunphy \& Hamrick (2007) found 
long-distance pollen movement, combined with almost total outcrossing, which was likely to be responsible for the low levels of population divergence and the relatively high genetic diversity for the neotropical tree Bursera simaruba (L.) Sarg. (Burseraceae).

Low genetic differentiation among forest fragments and vegetation corridors of secondary forest was observed in a previous allozyme study of $P$. spruceanum (Vieira \& Carvalho 2008). Male and female trees can differ in their attractiveness to pollinators; staminate flowers provide pollen and mostly nectar, whereas pistillate flowers often have only nectar (Bawa 1990). Consequently, the main advantage of dioecy may be avoidance of selfing. This might result in more fruit set in comparison with monoecious and hermaphroditic plant species ( $73.8 \%$ vs. $42.1 \%$ ) (Sutherland \& Delph 1984). Indeed, vegetation corridors presented high gene diversity $\left(H_{e}=0.420\right)$, and absence of inbreeding (Vieira \& Carvalho 2008). Nevertheless, further studies of sex ratio variation, spatial distribution and parentage analysis (Dunphy \& Hamrick 2007, Pavón \& Ramírez 2008) across the vegetation corridors are necessary to provide a clear picture of the contribution of seed and pollen to the overall contemporary gene immigration. The comparison between historical estimates of gene flow using variance in allelic frequencies, and contemporary estimates of gene flow using parentage assignment or reproductive biology data is expected to provide insights into ecological and evolutionary processes at regional landscape within and among populations.

Acknowledgments - The authors acknowledge Grazielle S. Teodoro for help during field work. Dra. Giovana A. Torres and Dra. Roselaine C. Pereira for their contributions in pollen tube growth analysis. Dr. Geoff Carr for his suggestions on the manuscript. The Coordenação de Aperfeiçoamento de Pessoal de Nível Superior (Capes) and the Conselho Nacional de Pesquisa $(\mathrm{CNPq})$ are also ackowledged for providing a $\mathrm{PhD}$ fellowship for F.A. Vieira, a research fellowship for Dr. Dulcinéia de Carvalho, and a research grant.

\section{References}

ARROYO, M.T.K., ARMESTO, J.J. \& PRIMACK, R. 1985. Community studies in pollination ecology in the high temperate Andes of Central Chile II. Effect of temperature on visitation rates and pollination possibilities. Plant Systematics and Evolution 149:187-203.

BAWA, K.S. 1990. Plant-pollinator interactions in tropical rain forests. Annual Review of Ecology and Systematics 21:399-422.
CARMO, R.M., FRANCESCHINELLI, E.V. \& SILVEIRA, F.A. 2004. Introduced honeybees (Apis mellifera) reduce pollination success without affecting the floral resource taken by native pollinators. Biotropica 36 : 371-376.

CRAWFORD, P.T. \& ELISENS, W.J. 2006. Genetic variation and reproductive system among North American species of Nuttallanthus (Plantaginaceae). American Journal of Botany 93:582-591.

DALY, D.C. 1992. New taxa and combinations in Protium Burm. f. Studies in neotropical Burseraceae VI. Brittonia 44:280-299.

DICK, C.W., ETCHELECU, G. \& AUSTERLITZ, F. 2003. Pollen dispersal of tropical trees (Dinizia excelsa: Fabaceae) by native insects and African honeybees in pristine and fragmented Amazonian rainforest. Molecular Ecology 12:753-764.

DOLIGEZ, A. \& JOLY, H.I. 1997. Genetic diversity and spatial structure within a natural stand of a tropical forest tree species, Carapa procera (Meliaceae), in French Guiana. Heredity 79:72-82.

DUNPHY, B.K. \& HAMRICK, J.L. 2007. Estimation of gene flow into fragmented populations of Bursera simaruba (Burseraceae) in the dry-forest life zone of Puerto Rico. American Journal of Botany 94:1786-1794.

FARWIG, N., RANDRIANIRINA, E.F., VOIGT, F.A., KRAEMER, M. \& BÖHNING-GAESE, K. 2004. Pollination ecology of the dioecious tree Commiphora guillauminii in Madagascar. Journal of Tropical Ecology 20:307-316.

GROSS, C.L. 2001. The effect of introduced honeybees on native bee visitation and fruit-set in Dillwynia juniperina (Fabaceae) in a fragmented ecosystem. Biological Conservation 102:89-95.

GUPTA, P., SHIVANNA, K.R. \& MOHAN RAM, H.Y. 1996. Apomixis and polyembryony in guggul plant, Commiphora weightii. Annals of Botany 78:67-72.

KEARNS, C.A. \& INOUYE, D.W. 1993. Techniques for pollination biologists. University Press, Niwot.

MATEU-ANDRÉS, I. \& PACO, L. DE. 2006. Genetic diversity and the reproductive system in related species of Antirrhinum. Annals of Botany 98: 1053-1060.

MORELLATO, L.P.C., TALORA, D.C., TAKAHASI, A., BENCKE, C.C., ROMERA, E.C. \& ZIPPARRO, V.B. 2000. Phenology of the Atlantic rain forest trees: a comparative study. Biotropica 32:811-823.

OLIVEIRA FILHO, A.T. \& RATTER, J.A. 1995. A study of the origin of central Brazilian forests by the analysis of the plant species distributions. Edinburgh Journal of Botany 52:141-194.

PAVÓN, N.P. \& RAMÍREZ, I.L. 2008. Sex ratio, size distribution and nitrogen resorption in the dioecious tree species Bursera morelensis (Burseraceae). Journal of Tropical Ecology 24:463-466. 
RAMALHO, M. 1990. Foraging by stingless bees of the genus Scaptotrigona (Apidae Meliponinae). Journal Apicultural Research 29:61-67.

SCHAIK, C.P. VAN, TERBORGH, J.W. \& WRIGHT, S.J. 1993. The phenology of tropical forests: adaptive significance and consequences for primary consumers. Annual Review of Ecology and Systematics 24:353-377.

STREIFF, R., LABBÉ, T., BACILIERI, R., STEINKELLNER, H., GLÖSSL, J. \& KREMER, A. 1998. Withinpopulation genetic structure in Quercus robur L.; Quercus petraea (Matt.) Liebl. assessed with isozymes and microsatellites. Molecular Ecology 7:317-328.

SUNNICHAN, V.G., RAM, H.Y.M. \& SHIVANNA, K.R. 2005. Reproductive biology of Boswellia serrata, the source of salai guggul, an important gum-resin. Botanical Journal of the Linnean Society 147:73-82.

SUTHERLAND, S. \& DELPH, L.F. 1984. On the importance of male fitness in plants: patterns of fruit-set. Ecology 65:1093-1104.
SUZUKI, N. 2003. Significance of flower exploding pollination on the reproduction of the Scotch broom, Cytisus scoparius (Leguminosae). Ecological Research 18:523-532.

VIEIRA, F.A. \& CARVALHO, D. 2008. Genetic structure of an insect-pollinated and bird-dispersed tropical tree in vegetation fragments and corridors: implications for conservation. Biodiversity and Conservation 17:23052321.

VOIGT, F.A., JUNG, S., FARWIG, N. \& BÖHNINGGAESE, K. 2005. Low fruit set in a dioecious tree: pollination ecology of Commiphora harveyi in South Africa. Journal of Tropical Ecology 21: 179-188.

WARD, M., DICK, C.W., GRIBEL, R., LEMES, M., CARON, H. \& LOWE, A.J. 2005. To self, or not to selfy: a review of outcrossing and pollenmediated gene flow in neotropical trees. Heredity 95: 246-254. 
